\title{
Immune Interferon Inhibits Proliferation and Induces 2'-5'-Oligoadenylate Synthetase Gene Expression in Human Vascular Smooth Muscle Cells
}

\author{
Stephen J. C. Warner, Gary B. Friedman, and Peter Libby \\ Department of Medicine (Cardiology), New England Medical Center; and U. S. Department of Agriculture \\ Human Nutrition Research Center on Aging, Tufts University, Boston, Massachusetts 02111
}

\begin{abstract}
Proliferation of vascular smooth muscle cells (SMC) contributes to formation of the complicated human atherosclerotic plaque. These lesions also contain macrophages, known to secrete SMC mitogens, and T lymphocytes. Many of the SMC in the lesions express class II major histocompatibility antigens, an indication that activated $\mathrm{T}$ cells secrete immune IFN- $\boldsymbol{\gamma}$ locally in the plaque. We therefore studied the effect of IFN- $\gamma$ on the proliferation of cultured SMC derived from adult human blood vessels. IFN- $\gamma(1,000 \mathrm{U} / \mathrm{ml})$ reduced [ ${ }^{3} \mathrm{H}$ ]thymidine (TdR) incorporation into DNA by SMC stimulated with the well-defined mitogens IL 1 (from $15.3 \pm 0.7$ to $6.2 \pm 0.7 \mathrm{dpm}$ $\times 10^{-3} / 24 \mathrm{~h}$ ) or platelet-derived growth factor (PDGF) (from $18.5 \pm 1.0$ to $\left.7.3 \pm 0.7 \mathrm{dpm} \times 10^{-3} / 24 \mathrm{~h}\right)$. Kinetic and nuclear labeling studies indicated that this effect of IFN- $\gamma$ was not due to altered thymidine transport or specific radioactivity of $\mathrm{TdR}$ in the cell. In longer term experiments (4-16 d) IFN- $\gamma$ prevented net DNA accumulation by SMC cultures stimulated by PDGF. IFN- $\gamma$ also delayed (from 30 to $60 \mathrm{~min}$ ) the time to peak level of c-fos RNA in IL 1-treated SMC.

It is unlikely that cytotoxicity caused these effects of IFN- $\gamma$, as the inhibition of growth was reversible and we detected no cell death in SMC cultures exposed to this cytokine. Activation of $2^{\prime}-5^{\prime}$ oligoadenylate synthetase gene expression may mediate certain antiproliferative and antiviral effects of interferons. Both IFN- $\gamma$ and type I IFNs (IFN- $\alpha$ or IFN- $\beta$ ) induced 2 ' -5 ' oligoadenylate synthetase mRNA and enzyme activity in SMC cultures, but with concentration dependence and time course that may not account for all of IFN- $\gamma$ 's cytostatic effect on SMC. The accumulation of SMC in human atherosclerotic lesions is a long-term process that must involve altered balance between growth stimulatory and inhibitory factors. The cytostatic effect of IFN- $\gamma$ on human SMC demonstrated here may influence this balance during human atherogenesis, because $T$ cells present in the complicated atherosclerotic plaque likely produce this cytokine.
\end{abstract}

\section{Introduction}

In humans, the formation of complicated atheromatous plaques may require decades. One important feature of this

Address reprint requests to Dr. Peter Libby, Department of Medicine, Division of Cardiology, Tufts University School of Medicine, 711 Washington Street, Boston, MA 02111.

Received for publication 25 July 1988 and in revised form $10 \mathrm{Oc}$ tober 1988.

J. Clin. Invest.

(c) The American Society for Clinical Investigation, Inc.

$0021-9738 / 89 / 04 / 1174 / 09 \$ 2.00$

Volume 83, April 1989, 1174-1182 long-term process is excessive proliferation of vascular smooth muscle cells (SMC) ${ }^{1}$ (1). Much work over the last decade has focused on the characterization of mediators that promote growth of these cells. For example, adherent platelets or infiltrating monocytes are a source of several SMC mitogens including platelet-derived growth factor (PDGF) (1-4), IL 1 (5), and transforming growth factor-alpha (6). Potential inhibitors of SMC proliferation have generally received less attention, although the degree of net SMC growth is likely to be determined by the balance between positive and negative stimuli over the years often required to form these lesions. Heparinlike molecules synthesized by vascular wall cells provide one example of a potential endogenous inhibitor of SMC proliferation (7). We have recently found that $\mathrm{PGE}_{2}$, a product of both vascular endothelial and smooth muscle cells can limit proliferation of human SMC in the short term $(<4 \mathrm{~d})$, after which these cells become refractory to this effect (5).

Another potential negative regulator of SMC growth in vivo is suggested by the surprising demonstration of immunocompetent cells in advanced human atherosclerotic lesions. Recent histological studies using well-defined, cell type-specific antisera not only confirmed the long-suspected presence of macrophages, but disclosed that $\mathrm{T}$ lymphocytes comprise up to $20 \%$ of the cells in regions of human atheromata (8-10). Many of the SMC in these lesions also bear class II major histocompatibility antigens (HLA DR ${ }^{+}$SMC) (11). Under usual circumstances, vascular SMC do not express these antigens, and the only known inducer of class II MHC expression in these cells is immune IFN, also known as gamma IFN $($ IFN- $\gamma)(12-14)$. T lymphocytes are a potential source of IFN- $\gamma$ within the atheroma (15-17). Taken together, these various findings indicate that human plaques contain a population of SMC that have been exposed to this cytokine.

Because IFN- $\gamma$ is antiproliferative for some cell types, including human vascular endothelial cells (18-26), we tested the hypothesis that this cytokine can also inhibit growth of human SMC. This issue requires careful investigation because IFN- $\gamma$ can interfere with thymidine transport in some cell types, and thus confound methods commonly used to assess the growth of cultured cells (27). Furthermore, IFN- $\gamma$, under certain circumstances, can promote the growth of some mesenchymal cells (28). We show here that IFN- $\gamma$ inhibits the IL 1- or PDGF-stimulated growth of SMC cultured from adult humans, modulates the kinetics of c-fos mRNA induction by mitogens, and activates expression by SMC of the 2'-5'-oligoadenylate synthetase gene that encodes an enzyme thought to

1. Abbreviations used in this paper: HSVSMC, human saphenous vein smooth muscle cells; IT, serum-free chemically defined medium supplemented with $1 \mu \mathrm{M}$ insulin and $5 \mu \mathrm{g} / \mathrm{ml}$ transferrin; Oligo-A, oligoadenylate; PDGF, platelet-derived growth factor; PDS, plasma-derived serum; SMC, smooth muscle cells; TdR, tritiated thymidine. 
mediate certain effects of IFN on mammalian cells $(22,23$, 25). These results suggest hitherto unsuspected interplay between cells of the immune system and the regulation of growth of human SMC. Modulation of the responsiveness of SMC to mitogenic stimuli by IFN- $\gamma$ may contribute to regulation of the growth state and other SMC functions in the pathogenesis of human vascular diseases.

\section{Methods}

\section{Cell culture and characterization}

(a) Human saphenous vein smooth muscle cells. Human saphenous vein smooth muscle cells (HSVSMC) were isolated from outgrowths of explants of unused portions of veins harvested for coronary artery bypass surgery (5). The endothelium was removed enzymatically and the adventitia was removed by blunt and sharp dissection before culture of the explants. This use of normally discarded tissue was approved by the Human Investigation Review Committee of New England Medical Center. The cells were maintained in DME that contains $5.5 \mathrm{mM}$ glucose, $25 \mathrm{mM}$ Hepes (M. A. Bioproducts, Walkersville, $\mathrm{MD}$ ), and 10\% FCS (Hyclone Laboratories, Logan, UT).

Low concentrations of bacterial endotoxin $(<100 \mathrm{pg} / \mathrm{ml})$ can activate these cells to produce endogenous IL 1 (29). Endotoxin contamination of tissue culture reagents could complicate study of the effects of exogenous cytokines. Therefore, constituents of tissue culture media were screened for endotoxin contamination using the quantitative chromogenic Limulus amoebocyte lysate assay (QCL 1000; M. A. Bioproducts). Only materials with endotoxin levels $<40 \mathrm{pg} / \mathrm{ml}$ are used in these experiments. The endotoxin antagonist polymyxin B (10 $\mu \mathrm{g} / \mathrm{ml}$; Sigma Chemical Co., St. Louis, MO) was included in most experimental incubations, although this precaution does not necessarily neutralize all endotoxins (30).

The cells cultured from saphenous veins (passages 3-5) exhibited typical morphologic characteristics of vascular smooth muscle in vitro, including a pattern of growth in hills and valleys (31). Even after several passages in culture many of these cells stained with HHF-35, a $\mathrm{MAb}$ that selectively recognizes muscle forms of actin and that does not react with endothelial cells or fibroblasts (32).

(b) Human arterial smooth muscle cells. Aortic SMC were isolated enzymatically from the inner third of the tunica media of human aortic tissues obtained from organ donors, with the cooperation of the New England Organ Bank (5). The adventitia and abluminal twothirds of the tunica media were removed before dissociation of the tissue with collagenase. Culture and characterization of these cells was as described above for venous SMC.

\section{Assay of growth of human smooth muscle cells}

(a) Thymidine uptake. For growth assays, cells were subcultured into 96-multi-well plates at $1.25-2.30 \times 10^{5}$ cells $/ \mathrm{cm}^{2}$ and used for experiments $2 \mathrm{~d}$ after subculture. Before initiation of growth studies, these cultures were placed for one day in medium composed of equal parts of DME and Ham's F-12 medium (Gibco, Grand Island, NY) (DME/F12) lacking serum but supplemented with insulin $(1 \mu \mathrm{M})$ and transferrin $(5 \mu \mathrm{g} / \mathrm{ml})$ (Collaborative Research, Bedford, MA), a medium denoted IT (33). This incubation in serum-free medium deprives the cells of serum-associated mitogens, arrests growth, and synchronizes cell proliferation in response to mitogens being assayed. Cultures prepared in this manner exhibited little or no basal c-fos mRNA level but rapid and brief c-fos expression after mitogen exposure, consistent with their initial quiescence and synchronous response to growth stimuli (5). Cultures were then incubated at $37^{\circ} \mathrm{C}$ for $2 \mathrm{~d}$ under various conditions and the incorporation of $\left[{ }^{3} \mathrm{H}\right]$ thymidine $(\mathrm{TdR})(6.7 \mathrm{Ci} / \mathrm{mmol} ; \mathrm{ICN}$ Radiochemicals, Irvine, CA) was measured in these short-term assays by addition of the $\left[{ }^{3} \mathrm{H}\right] \mathrm{TdR}(0.25 \mu \mathrm{Ci} / \mathrm{ml})$ during the second $24 \mathrm{~h}$ of the 2-d incubation. This schedule of labeling maximizes TdR incorpora- tion by mitogen-stimulated HSVSMC. At the end of the incubation unincorporated precursor was removed by washing with distilled water cell residues collected on nitrocellulose paper by an automated cell harvester. Radioactivity was measured by liquid scintillation spectroscopy, and efficiency of counting was determined by use of an external standard.

(b) DNA assay. DNA measurements were made on lysates of cell layers by a fluorimetric procedure based on binding of bisbenzamide $(5,34)$. After being washed with HBSS that lacks $\mathrm{Ca}^{2+}$ and $\mathrm{Mg}^{2+}$, the monolayers were treated with cold EDTA $(10 \mathrm{mM}, \mathrm{pH} 12.3)$ and incubated at $37^{\circ} \mathrm{C}$ for $20 \mathrm{~min} .1 \mathrm{M} \mathrm{KH}_{2} \mathrm{PO}_{4}$ was added to neutralize the lysate. After addition of bisbenzamide (Hoecht 33258; CalbiochemBehring Corp., La Jolla, CA) diluted to $200 \mathrm{ng} / \mathrm{ml}$ in $100 \mathrm{mM} \mathrm{NaCl}$ and $10 \mathrm{mM}$ Tris $\mathrm{pH} 7.0$, the samples were read in an automated microplate fluorometer (Dynatech Microfluor, Dynatech Laboratories, Alexandria, VA) with calf thymus DNA (Sigma Chemical Co.) as standard. This assay is sensitive to $50 \mathrm{ng}$ of DNA, and correlation coefficients for standard curves were $>0.99$.

(c) Assessment of DNA synthesis by thymidine nuclear labeling. Target cells were plated at $3.0 \times 10^{4}$ cells $/ \mathrm{cm}^{2}$ on tissue culture chamber slides (Lab-Tek; Miles Laboratories, Naperville, IL) and growth arrested for $4 \mathrm{~d}$ as described above. $18 \mathrm{~h}$ after addition of test samples $\left[{ }^{3} \mathrm{H}\right] \mathrm{TdR}(2 \mu \mathrm{Ci} /$ well) was added to each chamber. After $24 \mathrm{~h}$, the cell layer was washed with HBSS, fixed in absolute methanol for 45 min, washed, and air dried. The slides were dipped in emulsion NBT-2 (Eastman Kodak, Rochester, NY), air dried, and stored at $4^{\circ} \mathrm{C}$ in dark boxes with dessicant. After $12 \mathrm{~d}$, these slides were developed in D-19, fixed in Ektaflow (Eastman Kodak) and counterstained with hematoxylin (type III; Sigma Chemical Co.) to visualize unlabeled nuclei. The labeling index was calculated by counting 15 random high-power microscopic fields (400X, 30-90 nuclei/field) in each condition to quantitate the fraction of cells passing through $S$ phase during the time of exposure to labeled precursor. This method is little affected by variations in the specific radioactivity of the TdR precursor pool, which depends on thymidine transport and other factors.

\section{$\left(2^{\prime}-5^{\prime}\right)$-Oligoadenylate synthetase enzyme assay}

This assay was adapted from Revel et al. (35). Cell layers were washed with $140 \mathrm{mM} \mathrm{KCl} 3 \mathrm{mM} \mathrm{Mg}$ acetate, $35 \mathrm{mM}$ Tris- $\mathrm{HCl}$ (pH 7.6), and lysed in $200 \mu \mathrm{l}$ per well of buffer B: $0.5 \% \mathrm{NP}-40$ in $120 \mathrm{mM} \mathrm{KCl}, 5 \mathrm{mM}$ $\mathrm{Mg}$ acetate, $7 \mathrm{mM}$ 2-mercaptoethanol, $10 \%$ glycerol and $20 \mathrm{mM}$ Hepes (pH 7.5). The clarified lysates were stored at $4^{\circ} \mathrm{C}$ for up to $24 \mathrm{~h}$ before further assay. Poly (rl)-poly ( $\mathrm{rC}$ )-agarose (Pharmacia Fine Chemicals, Piscataway, NJ) equilibrated with buffer B (25 $\mu \mathrm{l}$ of a $50 \%$ [vol/vol] suspension was incubated with $50-75 \mu \mathrm{l}$ of the cell lysates at $30^{\circ} \mathrm{C}$ for $15 \mathrm{~min}, 1 \mathrm{ml}$ of buffer $\mathrm{B}$ was added. Synthesis of ${ }^{32} \mathrm{P}$-oligoadenylate by poly (rl)-poly( $\mathrm{rC}$ )-agarose-bound enzyme was measured by adding 10 $\mu \mathrm{l}$ of reaction mixture to the packed beads. This reaction mixture contained $5 \mathrm{mM}$ ATP, $2.5 \mathrm{mM}$ DTT; $20 \mathrm{mM} \mathrm{Mg}$ acetate, $25 \mathrm{mM} \mathrm{KCl}$ and $500-2,500 \mu \mathrm{Ci} / \mathrm{ml} \alpha-{ }^{32} \mathrm{P}-\mathrm{ATP}(800 \mathrm{Ci} / \mathrm{mmol}$; New England $\mathrm{Nu}-$ clear, Boston, MA). The tubes were incubated for $18 \mathrm{~h}$ at $30^{\circ} \mathrm{C} .8 \mu \mathrm{l}$ of Tris- $\mathrm{HCl}(20 \mathrm{mM}, \mathrm{pH} 8)$ were added to each tube and the beads were pelleted by centrifugation. $10 \mu \mathrm{l}$ of the supernatant was removed to new tubes containing $4 \mu \mathrm{l}$ of bacterial alkaline phosphatase $(100 \mathrm{U} / \mathrm{ml}$ in $0.17 \mathrm{M}$ Tris base, Sigma Chemical Co.). The reaction mixture was kept for $30 \mathrm{~min}$ at $37^{\circ} \mathrm{C}$, after which another $2 \mu \mathrm{l}$ of phosphatase was added and incubation continued for a further $30 \mathrm{~min}$. The dephosphorylation reaction was stopped by the addition of $1 \mathrm{ml}$ of glycine$\mathrm{HCl}(1 \mathrm{M}, \mathrm{pH} 2)$. Inorganic phosphate was separated from oligoadenylate cores by batch adsorption chromatography on alumina powder acid WAI (Sigma Chemical Co.). $250 \mathrm{mg}$ of the powder was washed with $1 \mathrm{ml}$ of glycine- $\mathrm{HCl}(1 \mathrm{M}, \mathrm{pH} 2)$, by vortexing and centrifugation. The supernatant was aspirated and replaced with the alkaline phosphatase-treated oligoadenylate synthetase reaction products $(1 \mathrm{ml})$. The tubes were agitated vigorously for $30 \mathrm{~min}$ at room temperature. A further $2 \mathrm{ml}$ of the glycine- $\mathrm{HCl}$, was added and the alumina pelleted by centrifugation for $5 \mathrm{~min}$ at $1,500 \mathrm{~g}$ ). ${ }^{32} \mathrm{P}$ in phosphatase-resistant oligoadenylate cores was determined by Cerenkov counting. 


\section{Assessment of specific $m R N A$ levels}

(a) Isolation of RNA and Northern analysis. Cultured cells were lysed in guanidinium isothiocyanate and RNA was purified by acid phenol extraction (36). RNA concentration was determined from the $A_{260}$, and $A_{260} / A_{280}$ ratios were $>2$. RNA was electrophoresed in agarose gels $(1.2 \%)$ containing $2.2 \mathrm{M}$ formaldehyde, transferred to nylon membranes (Hybond-N; Amersham Co., Arlington Heights, IL), and immobilized by shortwave ultraviolet illumination. The membranes were prehybridized for at least $2 \mathrm{~h}$ before hybridization according to standard protocols with ${ }^{32} \mathrm{P}$-labeled DNA probes labeled by random hexanucleotide priming (37) to specific activities $>10^{8} \mathrm{cpm} / \mu \mathrm{g}$ DNA, and autoradiographed.

(b) Nucleic acid probes. 2'-5'-Oligoadenylate synthetase mRNA was detected with a 1.3-kb Eco RI fragment of plasmid 9.21, a kind gift of Drs. M. Revel and J. Chebath of the Weizmann Institute, Rehovot, Israel (38). Beta-tubulin was detected with a 1.05-kb Bam HI-to-Pst I fragment subcloned into pSP65, and originally derived from R $\beta T .3$, a gift of Dr. Stephen R. Farmer, Boston University, Boston, MA (39). The mRNA of the oncogene c-fos was probed with a 3-kb Xho I-toNco I fragment derived from plasmid ATCC 41042 (American Type Culture Collections, Rockville, MD).

\section{Cytokines and antibodies}

Recombinant human leukocyte A IFN (IFN- $\alpha$ ) was obtained from Dr. Peter Sorter, Hoffman-La Roche, Inc., Nutley, NJ. Purified human IFN- $\beta\left(2.4 \times 10^{7} \mathrm{U} / \mathrm{mg}\right)$ was a product of Lee Biomolecular Research Inc., San Diego, CA. Dr. Jan Vilcek of New York University kindly provided bovine anti-human IFN- $\beta$ antibody. Recombinant human IFN- $\gamma$ was supplied by Genentech Co., South San Francisco, CA. Recombinant human IL $1 \alpha$ was obtained from Dr. Peter Lomedico, Hoffman-La Roche, Inc., and recombinant IL $1 \beta$ was obtained from Dr. Charles A. Dinarello, Tufts University, Boston, MA. Recombinant

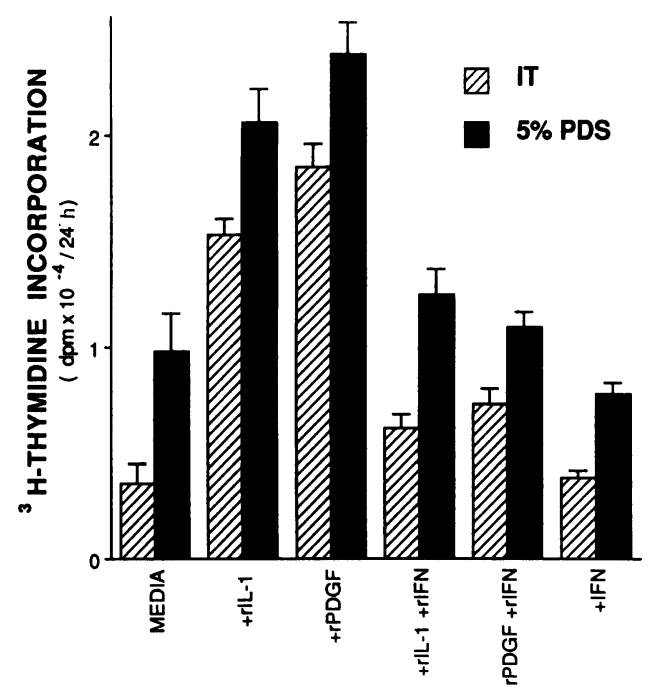

Figure 1. rIFN- $\gamma$ reduces $\left[{ }^{3} \mathrm{H}\right] \mathrm{TdR}$ incorporation by human SMC treated with rIL-1 and rPDGF. Cultures of HSVSMC were plated at $1.25 \times 10^{5}$ cells $/ 0.32 \mathrm{~cm}^{2}$ in DME supplemented with $10 \%$ FCS. After a 1-d incubation in IT (a chemically-defined serum-free medium), the medium was replaced with either fresh IT ( $($ ) or DME supplemented with plasma-derived serum (PDS, 5\%) (an undefined medium low in intrinsic mitogenic activity, but that contains many plasma factors lacking in the chemically-defined media) (๓). All conditions contained $1 \mu \mathrm{g} / \mathrm{ml}$ indomethacin. The effect of $1,000 \mathrm{U} / \mathrm{ml}$ rIFN- $\gamma$ was determined alone or with $1.0 \mathrm{ng} / \mathrm{ml}$ rIL $1 \alpha$ or PDDGF $_{\mathrm{v}}$. sis $(10 \mathrm{ng} / \mathrm{ml})$ in both of the media. TdR incorporation was measured over the second $24-\mathrm{h}$ period of a $2-\mathrm{d}$ incubation. The data are mean $\pm \mathrm{SD}, n=8$.

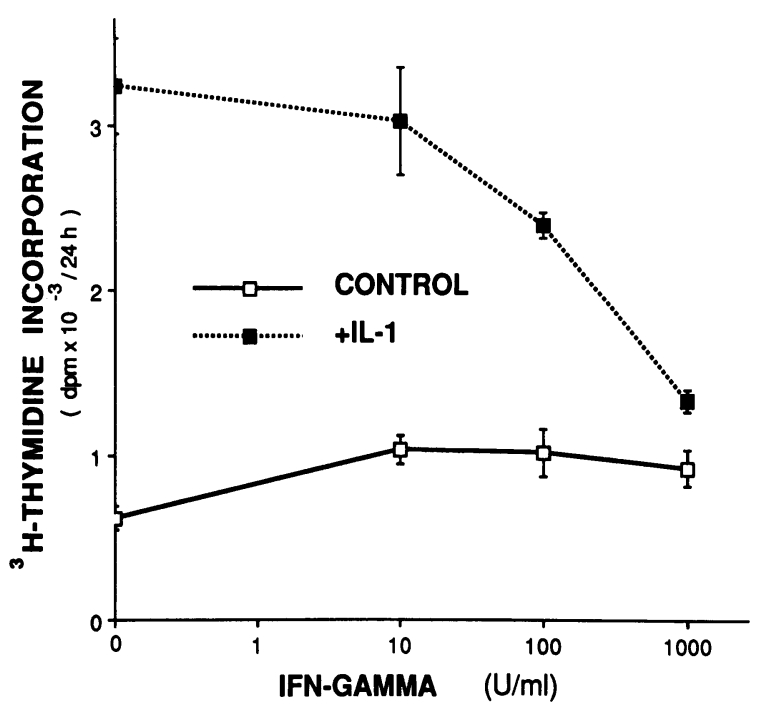

Figure 2. Concentration-dependent inhibition by rIFN- $\gamma$ of $\left[{ }^{3} \mathrm{H}\right] \mathrm{TdR}$ incorporation by HSVSMC stimulated with rIL 1 . Cultures of HSVSMC were plated at $7.4 \times 10^{5}$ cells $/ 0.32 \mathrm{~cm}^{2}$ in DME supplemented with $10 \%$ FCS. After a 1-d incubation in IT, the medium was replaced with fresh IT and $1 \mu \mathrm{g} / \mathrm{ml}$ indomethacin, supplemented with either $0-1,000 \mathrm{U} / \mathrm{ml} \mathrm{rIFN-} \gamma$ and $1.0 \mathrm{ng} / \mathrm{ml} \mathrm{rIL} 1 \alpha(---)$, or $0-1,000 \mathrm{U} / \mathrm{ml}$ IFN- $\gamma$ alone (-). TdR incorporation was measured over the second 24-h period of a 2-d incubation. The data are mean $\pm \mathrm{SD}, n=6$.

v-sis product (PDGF) was supplied by Amgen Biologicals, Thousand Oaks, CA.

\section{Results}

Interferon- $\gamma$ inhibits mitogen-induced $\left[{ }^{3} H\right] T d R$ incorporation in HSVSMC. 1,000 U/ml IFN- $\gamma$ inhibited $\left[{ }^{3} \mathrm{H}\right] \mathrm{TdR}$ incorporation by HSVSMC stimulated with either rPDGF or rIL 1 (Fig. 1, and data not shown). This effect of IFN- $\gamma$ was concentration dependent (Fig. 2) and occurred in cultures maintained in a defined serum-free medium containing insulin and transferrin (IT), or in plasma-derived serum (PDS, 5\%), a supplement low in intrinsic mitogenic activity, but one that contains many plasma factors lacking in the chemically defined medium IT (40) (Fig. 1).

In certain cell types, IFN- $\gamma$ inhibits thymidine transport (27). To assess whether the effect of IFN- $\gamma$ on $\left[{ }^{3} \mathrm{H}\right] \mathrm{TdR}$ incorporation in HSVSMC reflected an IFN- $\gamma$-induced reduction in $\left[{ }^{3} \mathrm{H}\right] \mathrm{TdR}$ transport and consequent alteration in the specific radioactivity of the precursor pool for DNA synthesis, we measured TdR transport in the absence or presence of IFN- $\gamma$. In synchronized SMC cultures $1 \mathrm{~d}$ after mitogen stimulation, $\left[{ }^{3} \mathrm{H}\right] \mathrm{TdR}$ incorporation into the acid-insoluble fraction (DNA) increased linearly, whereas the $\left[{ }^{3} \mathrm{H}\right] \mathrm{TdR}$ in the acid-soluble fraction (cytoplasmic pool) reached a plateau in $<5 \mathrm{~min}$ (data not shown). We measured acid-soluble radioactivity after a 2-min incubation period as an index of the initial velocity of thymidine transport. Treatment with IFN- $\gamma$ did not signifcantly alter this process in cells treated with rIL 1, but produced a concentration-dependent increase in the rate of $\left[{ }^{3} \mathrm{H}\right]-$ TdR uptake into rPDGF-stimulated HSVSMC (data not shown). These observations render unlikely the possibility that IFN- $\gamma$ inhibits $\left[{ }^{3} \mathrm{H}\right] \mathrm{TdR}$ incorporation into acid-insoluble ra- 

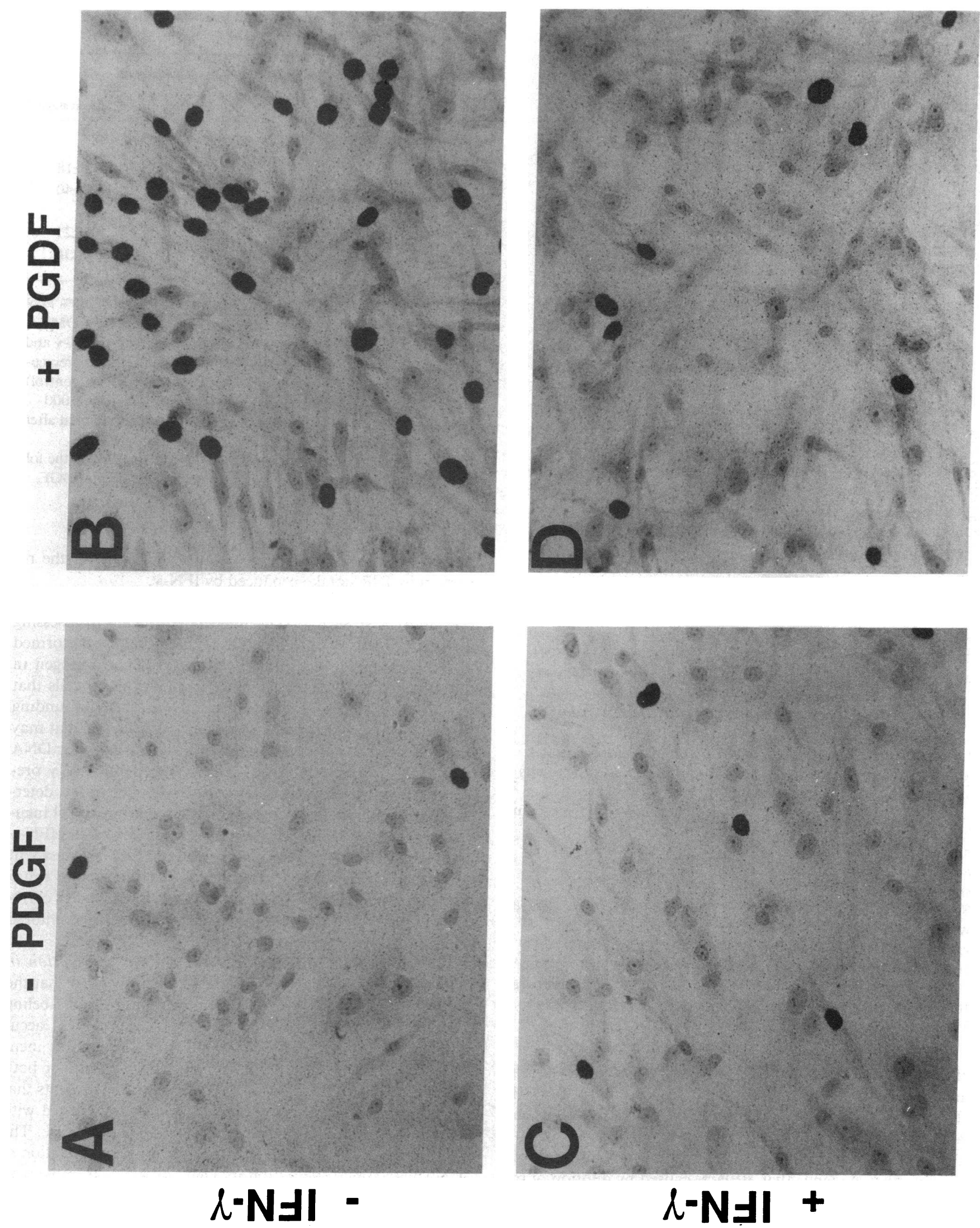

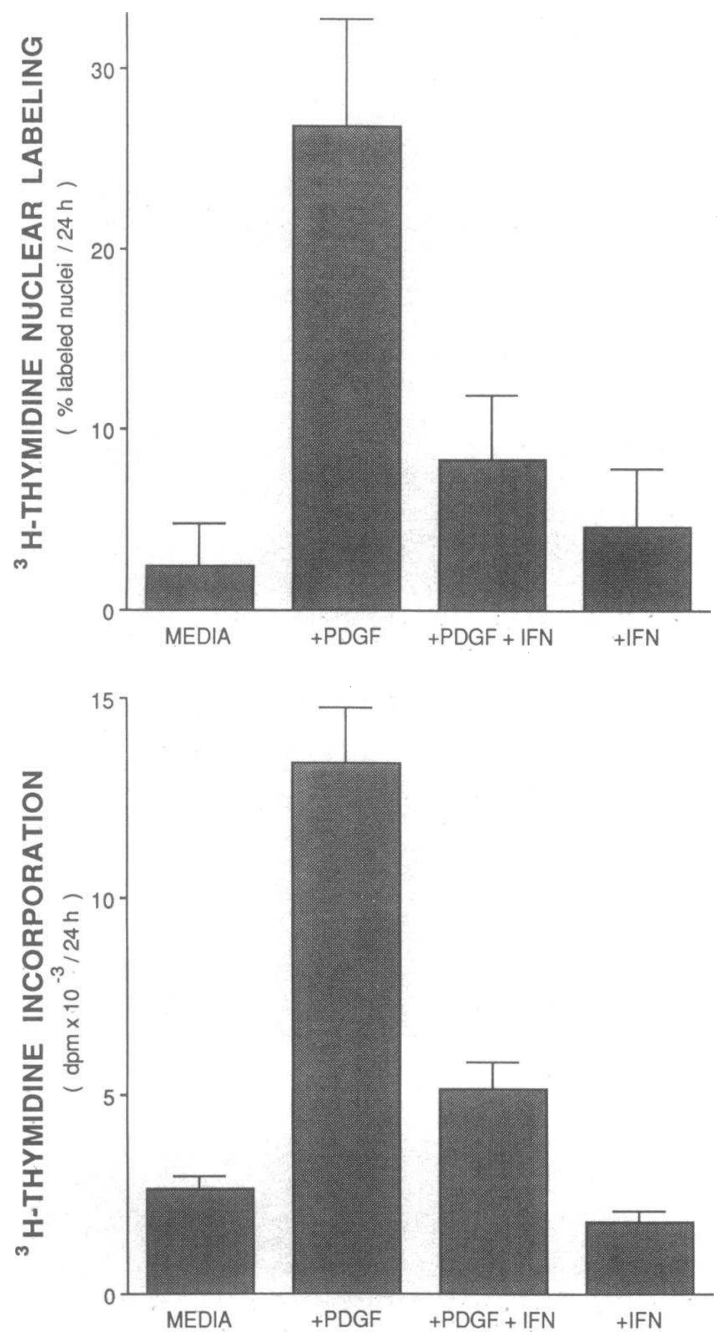

Figure 4. Comparison of effects of rIFN- $\gamma$ on nuclear labeling and incorporation ${ }^{3} \mathrm{H}-\mathrm{TdR}$ in SMC treated with rPDGF. $(A)$ The results of the autoradiography presented in Fig. 3 were quantitated by counting the number of labeled vs. non-labeled nuclei in 15 random high-power fields $(400 \times)$ per condition (30-90 cells per field). The data are the mean \pm SD of 15 fields. $(B)$ Cultures of the same isolate of HSVSMC used in the autoradiographic experiment above were studied in parallel for incorporation of radioactive precursor TdR. SMC were plated at $6.1 \times 10^{5}$ cells $/ 0.32 \mathrm{~cm}^{2}$ in DME supplemented with $10 \%$ FCS for $1 \mathrm{~d}$. After a 1-d incubation in IT to produce growth arrest, the medium was replaced with either fresh IT, or IT supplemented with $10 \mathrm{ng} / \mathrm{ml} \mathrm{rPDGF} \mathrm{v}_{\mathrm{v} \text { sis }}, 10 \mathrm{ng} / \mathrm{ml} \mathrm{rPDGF} \mathrm{v}_{\mathrm{v} \text { sis }}$ $+1,000 \mathrm{U} / \mathrm{ml}$ rIFN- $\gamma$, or $1,000 \mathrm{U} / \mathrm{ml}$ rIFN- $\gamma$ alone. TdR incorporation was measured over the second 24-h period of a 2-d incubation. Data are mean $\pm \mathrm{SD}, n=8$.

dioactivity by decreasing $\left[{ }^{3} \mathrm{H}\right] \mathrm{TdR}$ transport. Other experiments showed that increasing the concentration of the $\left[{ }^{3} \mathrm{H}\right]-$ TdR in the medium 10-fold (from 0.25 to $2.5 \mu \mathrm{Ci} / \mathrm{ml}$ ) did not alter the inhibitory effect of IFN- $\gamma$ on TdR incorporation in PDGF or IL 1-treated SMC (data not shown). This result provides further evidence that artifacts caused by dilution of pre-
Table I. HSVSMC Respond to Mitogen Stimulation

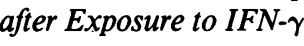

\begin{tabular}{|c|c|c|}
\hline & \multicolumn{2}{|c|}{ DNA content } \\
\hline & -IFN pretreatment* & + IFN pretreatment \\
\hline & \multicolumn{2}{|c|}{$n g /$ well } \\
\hline Control $(5 \% P D S)^{*}$ & $361 \pm 29$ & $292 \pm 18$ \\
\hline PDGF $(10 \mathrm{ng} / \mathrm{ml})^{*}$ & $847 \pm 111$ & $661 \pm 40$ \\
\hline \multicolumn{3}{|l|}{ PDGF $(10 n g / m l)$} \\
\hline$+\operatorname{IFN}-\gamma(1,000 \mathrm{U} / \mathrm{ml})^{*}$ & $562 \pm 33$ & $400 \pm 21$ \\
\hline IFN- $\gamma(1,000 \mathrm{U} / \mathrm{ml})$ & $292 \pm 14$ & $268 \pm 16$ \\
\hline
\end{tabular}

HSVSMC were plated at $9.6 \times 10^{3}$ cells $/ 0.32 \mathrm{~cm}^{2}$ in DME- $10 \%$ FCS. After a 2-d incubation in IT, the medium was replaced with DME supplemented with $5 \%$ PDS, with or without $1,000 \mathrm{U} / \mathrm{ml} \mathrm{IFN- \gamma \text {and }}$ preincubation continued for $4 \mathrm{~d}$. The IFN- $\gamma$ present during preincubation was then removed and replaced with medium alone (control), $10 \mathrm{ng} / \mathrm{ml}$ PDGF, $10 \mathrm{ng} / \mathrm{ml}$ PDGF $+1,000 \mathrm{U} / \mathrm{ml} \mathrm{IFN-} \gamma$, or 1,000 $\mathrm{U} / \mathrm{ml}$ IFN- $\gamma$ alone. DNA content of the cultures was measured after $8 \mathrm{~d}$. Data are mean $\pm \mathrm{SD}, n=8$.

* A 95\% significance level was obtained by ANOVA between the following groups: -IFN and +IFN pretreatment, control and PDGF, and PDGF and PDGF + IFN.

cursor pool-specific radioactivity do not account for the reduction in TdR uptake produced by IFN- $\gamma$.

IFN- $\gamma$ inhibits nuclear labeling with $\left[{ }^{3} \mathrm{H}\right] T d R$ in mitogenstimulated HSVSMC. As an independent means of assessing the effect of IFN- $\gamma$ on HSVSMC proliferation we performed autoradiography of cells treated with IFN- $\gamma$ and mitogen in the presence of $\left[{ }^{3} \mathrm{H}\right] \mathrm{TdR}$. This technique labels all cells that have traversed $S$ phase and is insensitive to the confounding influence of transport phenomena and other factors that may alter the specific radioactivity of the precursor pool for DNA synthesis. Treatment of cells with $1,000 \mathrm{U} / \mathrm{ml}$ IFN- $\gamma$ prevented the mitogen-induced increase in labeling index, determined by autoradiography (Figs. 3 and $4 A$ ). In parallel incubations of HSVSMC from the same isolate, $1,000 \mathrm{U} / \mathrm{ml} \mathrm{IFN-} \gamma$ inhibited $\left[{ }^{3} \mathrm{H}\right] \mathrm{TdR}$ incorporation (Fig. $4 \mathrm{~B}$ ). The consistent inhibitory effect of IFN- $\gamma$ on $\left[{ }^{3} \mathrm{H}\right] \mathrm{TdR}$ incorporation by mitogen-stimulated HSVSMC (Figs. 1 and $4 B$, Table I) thus correlated directly with a decrease in DNA synthesis monitored independently by nuclear labeling.

IFN- $\gamma$ inhibits mitogen-induced DNA accumulation in long-term HSVSMC cultures. To determine whether that the inhibitory effect of IFN- $\gamma$ on TdR incorporation and labeling index actually reflected sustained changes in net DNA accumulation, we measured the DNA content of cultures incubated with PDGF alone, 1,000 U/ml IFN- $\gamma$ alone, or both agents together over a longer term than the experiments that used radioactive precursors (Fig. 5). In cultures treated with PDGF, DNA content increased during $16 \mathrm{~d}$ in culture. The addition of IFN- $\gamma$ completely prevented this accumulation of DNA with time. The inhibitory effect of IFN- $\gamma$ is unlikely to

Figure 3. rIFN- $\gamma$ inhibits nuclear labeling by $\left[{ }^{3} \mathrm{H}\right] \mathrm{TdR}$ in HSVSMC stimulated by rPDGF. HSVSMC were sub-cultured at 6.0 $\times 10^{4}$ cells $/ 2.0 \mathrm{~cm}^{2}$ into four-chambered tissue-culture glass slides in DME supplemented with $10 \%$ FCS. After a 4-d incubation in IT, the medium was replaced with either $(A)$ fresh IT alone, $(B)$ IT supplemented with $5 \mathrm{ng} / \mathrm{ml} \mathrm{rPDGF} \mathrm{v}_{\mathrm{v}-s i s},(C) 1,000 \mathrm{U} / \mathrm{ml} \mathrm{rIFN}-\gamma$ alone, or $(D)$ $\mathrm{rPDGF}_{\mathrm{v}-\mathrm{sis}}+\mathrm{rIFN}-\gamma$. The slides were treated for autoradiography, and counterstained with hematoxylin. The photomicrographs show representative fields, nuclei resulting from cell divisions during exposure to the labeled precursor TdR are darkened by the silver grains. 


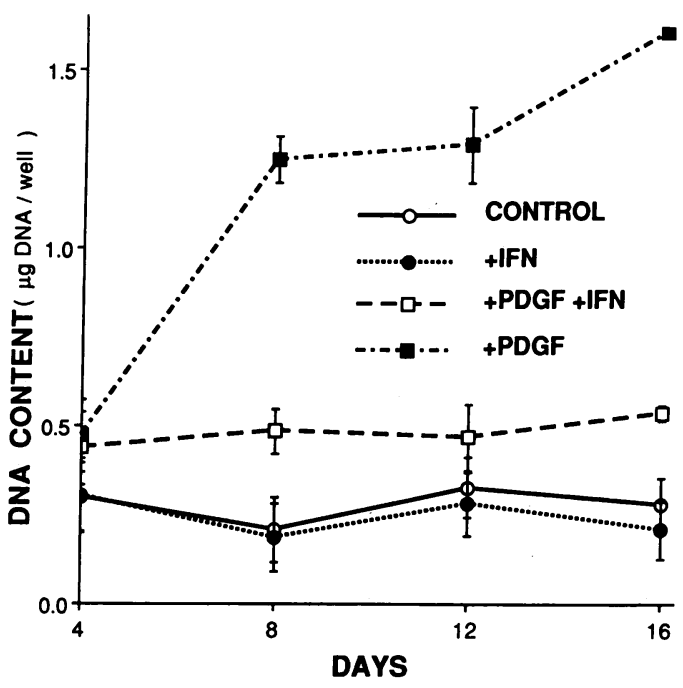

Figure 5. rIFN- $\gamma$ inhibits accumulation of DNA by cultures of PDGF-treated HSVSMC. Replicate cultures of HSVSMC were plated at $9.6 \times 10^{3}$ cells $/ 0.32 \mathrm{~cm}^{2}$ in DME supplemented with $10 \%$ FCS. After a 2-d incubation in IT to produce growth arrest, the medium was replaced with DME supplemented with 5\% PDS alone (o) or with $10 \mathrm{ng} / \mathrm{ml} \mathrm{rPDGF} \mathrm{v}_{\mathrm{v} \text { sis }}(\boldsymbol{0}), 10 \mathrm{ng} / \mathrm{ml} \mathrm{rPDGF} \mathrm{v}_{\mathrm{v} \text { sis }}+1,000 \mathrm{U} / \mathrm{ml}$ rIFN- $\gamma(\square)$, or $1,000 \mathrm{U} / \mathrm{ml}$ rIFN- $\gamma$ alone $(\bullet)$ and refreshed every $4 \mathrm{~d}$. DNA content was assayed at 4, 8, 12, and $16 \mathrm{~d}$ (eight wells/condition/time point). Data are mean $\pm \mathrm{SD}, n=8$.

be attributable to cytotoxicity of the cytokine, as HSVSMC treated with IFN- $\gamma$ for $\mathbf{4} \mathrm{d}$ and then stimulated with PDGF in the absence of IFN- $\gamma$ still accumulated DNA (Table I). In addition, phase-contrast microscopy or photometric examination of HSVSMC cultures stained with crystal violet failed to demonstrate cytopathic effect or attrition of cells exposed to IFN- $\gamma$ (data not shown). Together, the above data indicate that IFN- $\gamma$ inhibits proliferation of HSVSMC selectively, rather than by nonspecific cytotoxic effect.

IFN- $\gamma$ alters the kinetics of c-fos protooncogene $m R N A$ induction after mitogen stimulation. We have previously shown in HSVSMC that both IL 1 and PDGF induce a transient increase in c-fos mRNA levels, which peak within 15-30 min after addition of mitogen to quiescent cultures (5). Simultaneous addition of $1,000 \mathrm{U} / \mathrm{ml}$ IFN- $\gamma$ and $1.0 \mathrm{ng} / \mathrm{ml}$ IL $1 \alpha$ to growth-arrested cultures of HSVSMC delayed the c-fos response twofold, so that the peak level occurred $60 \mathrm{~min}$ after mitogen addition (Fig. 6). Pretreatment with IFN- $\gamma$ for $24 \mathrm{~h}$ did not alter the rate of accumulation of IL 1 -induced c-fos mRNA, but did reduce the maximum steady-state level of this mRNA after IL 1 treatment (data not shown).

IFNs induce 2'-5' oligoadenylate synthetase gene expression in HSVSMC. In certain other cell types induction of the $2 '-5$-oligoadenylate synthetase enzyme (oligo-A synthetase) and consequent increase in the intracellular level of its products, oligoadenylate oligomers, may mediate the antiviral as well as the antiproliferative effect of IFNs $(22,23,25)$. Under basal conditions, cultured HSVSMC contain no oligo-A synthetase mRNA or enzyme activity. HSVSMC treated for $72 \mathrm{~h}$ with IFN- $\alpha$, IFN- $\beta$, or IFN- $\gamma$ (each at $1,000 \mathrm{U} / \mathrm{ml}$ ) contained oligo A synthetase mRNA that comigrated with the three sizes of transcript found in human diploid fibroblasts (WI-38 cells) treated with cycloheximide, poly I-poly C, and IFN- $\beta$ (25) (Fig.
7). Further experiments showed that treatment for $\geq 24 \mathrm{~h}$ with as little as $1 \mathrm{U} / \mathrm{ml}$ of IFN- $\alpha$ or $10 \mathrm{U} / \mathrm{ml}$ of IFN- $\gamma$ induced oligo-A synthetase mRNA (data not shown). The Type I IFN's ( $\alpha$ and $\beta$ ) induced higher levels of oligo-A synthetase mRNA than IFN- $\gamma$, as previously observed in other cells. The response to IFN- $\beta$ was abolished by anti-IFN- $\beta$ antiserum, indicating the selectivity of this induction (Fig. 7). To determine whether the induced oligo A synthetase mRNA correlated with appearance of enzyme activity, we assayed the enzyme in extracts of HSVSMC treated for $24 \mathrm{~h}$ with IFN- $\alpha$, IFN- $\beta$, or IFN- $\gamma$ $(0.1-1,000 \mathrm{U} / \mathrm{ml})$. IFN- $\alpha$ and IFN- $\beta$ treatment induced oligoA synthetase activity in a concentration-dependent manner (Fig. 8). In agreement with the steady-state RNA levels (Fig. 7), IFN- $\gamma$ induced less oligo-A synthetase activity than the type I IFN (Fig. 8).

\section{Discussion}

This study demonstrated, using several independent criteria, that IFN- $\gamma$ treatment inhibits the responses of cultured human vascular smooth muscle cells to IL 1 and PDGF, two growth factors of particular significance because they can be produced by cells of the vessel wall $(5,41-43)$. IFN- $\gamma$ added simultaneously with mitogen delayed the mitogen-induced increase in c-fos oncogene mRNA levels, an early consequence of growth factor activation of cells that characteristically occurs within minutes (Fig: 6). Prolonged exposure of SMC to IFN- $\gamma$ (over days to weeks) prevented mitogen-induced DNA accumula-
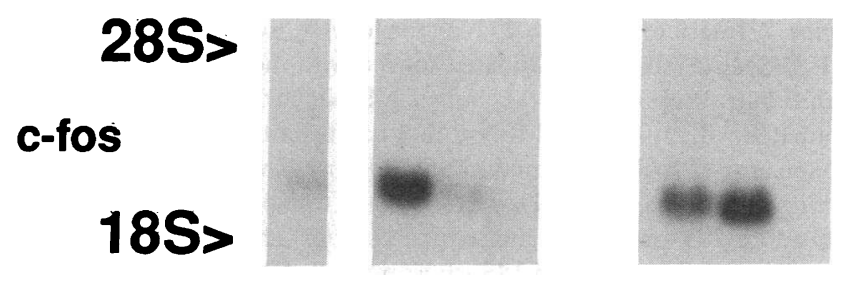

TIME (min)
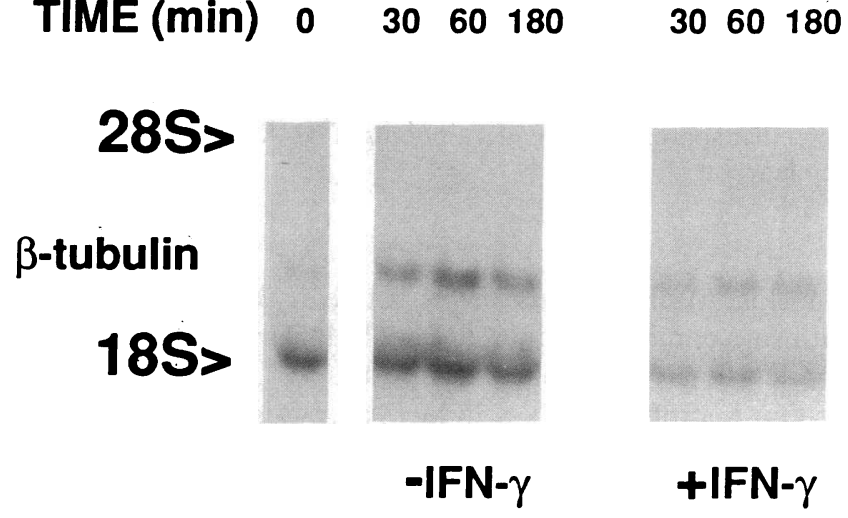

Figure 6. IFN- $\gamma$ delays the transient IL 1-induced increase in c-fos protooncogene mRNA levels in human SMC. Cells were incubated with $1.0 \mathrm{ng} / \mathrm{ml} \mathrm{IL} 1 \alpha$, with or without $1,000 \mathrm{U} / \mathrm{ml} \mathrm{IFN-} \gamma$ for the indicated time periods. $20 \mu \mathrm{g} /$ lane RNA was electrophoresed, transferred to nylon membrane, and hybridized with c-fos probe (top). The arrows indicate the position of migration of the $28 \mathrm{~S}$ and $18 \mathrm{~S}$ ribosomal subunits. The blot was stripped and rehybridized with $\beta$-tubulin probe (bottom) to confirm that approximately equal amounts of intact RNA were loaded in each lane. 

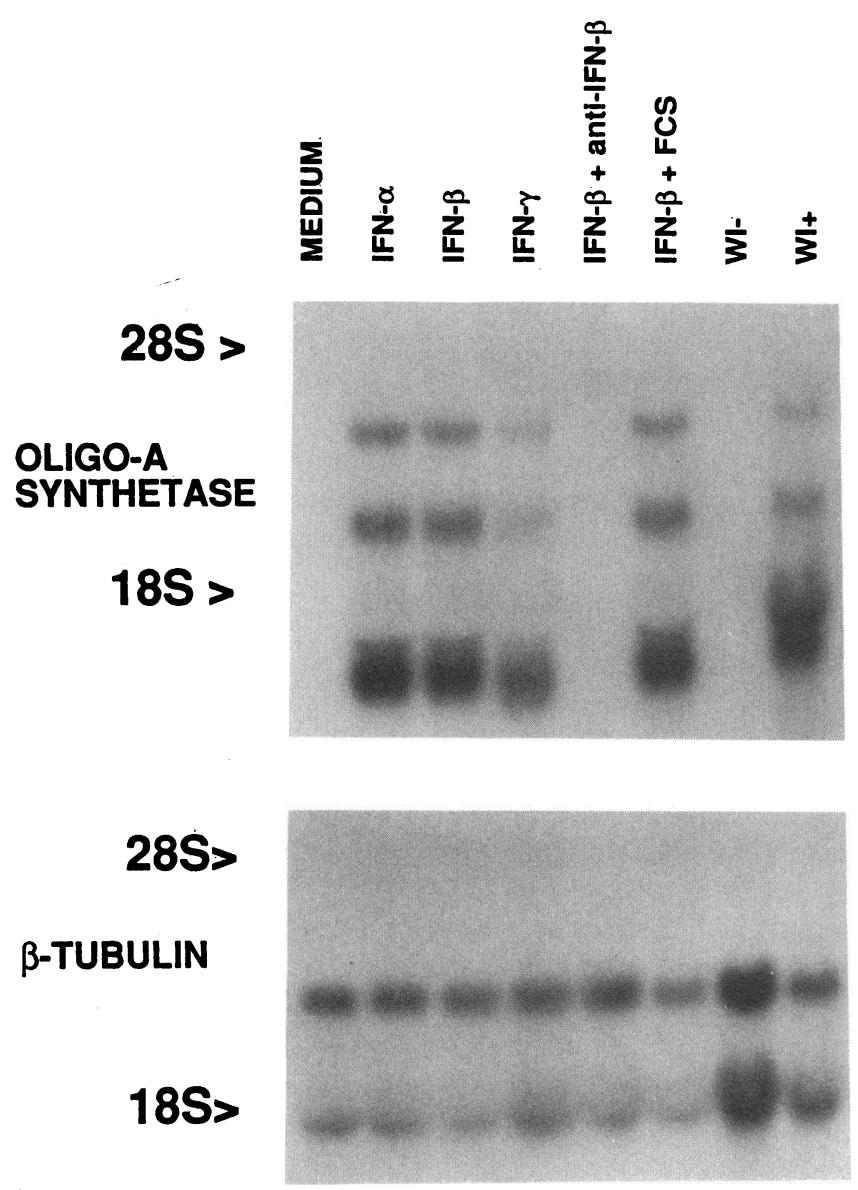

Figure 7. Interferons induce $2 '-5$ '-oligoadenylate synthetase mRNA in HSVSMC. Cells were incubated for $3 \mathrm{~d}$ with medium alone, or with IFN- $\alpha$, IFN- $\beta$, or $1,000 \mathrm{U} / \mathrm{ml}$ each IFN- $\gamma$. Some cells were also incubated with $1,000 \mathrm{U} / \mathrm{ml}$ IFN- $\beta$ that had been treated with either bovine anti-IFN- $\beta$ antiserum (1:166 dilution) or with nonimmune bovine serum. $20 \mu \mathrm{g}$ of RNA was subjected to Northern analysis and probed for $2^{\prime}-5^{\prime}$-oligoadenylate sequences (top). The arrows indicate the position of the $28 \mathrm{~S}$ and $18 \mathrm{~S}$ ribosomal subunits. In addition, RNA from WI38 fibroblasts that had been treated for $4 \mathrm{~h}$ with cycloheximide, poly I-poly C, and IFN- $\beta$ (WI + ), or control cells (WI-) was electrophoresed as positive and negative controls, respectively. The blot was stripped and rehybridized with $\beta$-tubulin probe (bottom), which confirms the integrity of the RNA on the blot, and shows that approximately equal amounts of RNA were loaded in each lane.

tion (Fig. 5). IFN- $\gamma$ thus affects both early and late events in pathways of mitogen stimulation of SMC, and may inhibit cell proliferation by multiple mechanisms.

Our finding that IFN- $\gamma$ induces oligo-A synthetase mRNA levels and enzyme activity in human vascular SMC suggests one possible mechanism of growth inhibition. This enzyme polymerizes ATP into oligomers that activate intracellular endoribonucleases that may degrade RNA, leading to reduced protein synthesis and thus contribute to both the antiviral and antiproliferative effects of IFNs $(22,23,25)$. The finding that IFNs lack these activities in cell strains deficient in this RNAase supports this concept $(22,23)$. In bovine SMC, serum-associated mitogens regulate the levels of c-myc and certain other growth-related mRNA species by decreased degradation rather than increased transcription (44). IFNs might

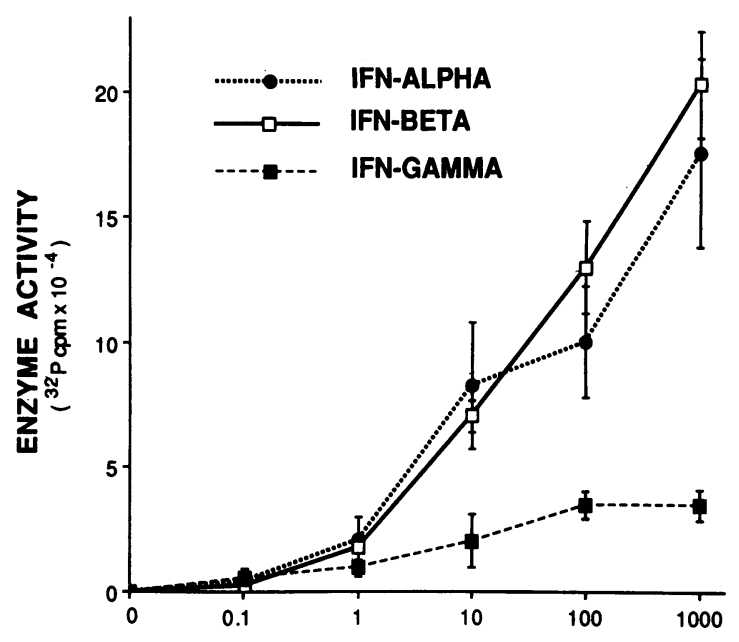

Figure 8 . IFNs induce 2'-5'-oligoadenylate synthetase enzyme activity in HSVSMC. Cells were incubated for $24 \mathrm{~h}$ with IFN- $\alpha(\bullet)$, IFN- $\beta$ (), or $0.1-1,000 \mathrm{U} / \mathrm{ml}$ IFN- $\gamma$ (ロ). 2'-5'-Oligoadenylate synthetase activity was measured in NP-40 cell lysates as described in Methods. Data are mean $\pm S D$ of individual determinations on triplicate or quadruplicate wells, and were corrected by subtraction of ${ }^{32} \mathrm{P}$ counts per minute measured when cell lysis buffer alone was subjected to the assay procedure.

therefore slow cell proliferation by activating intracellular RNAase activity that could degrade such labile messages. However, oligo A synthetase induction in human SMC (Figs. 7 and 8) is slower than at least some of the growth-related effects of IFN- $\gamma$ on these cells (Fig. 6), an indication that induction of this enzyme probably does not account for all of the cytostatic effects of IFN- $\gamma$ in vascular SMC.

The experiments reported here establish the effects of purified cytokines on homogeneous cell cultures. Although extrapolation of our results to intact human tissues remains hypothetical, Hansson and colleagues have recently shown that IFN- $\gamma$ inhibits rat SMC proliferation in vitro and in vivo after balloon catheter injury to the carotid artery (13). Their elegant in vivo experiments in rats suggest that class II-bearing SMC (i.e., the very cells likely to have been exposed to IFN- $\gamma$ ) proliferate less than cells which lack these determinants. In rabbits fed an atherogenic diet, concurrent administration of IFN inducers retards the development of aortic lesions (45). These various results in intact animals indicate that our results on cultured human cells may well apply in vivo.

These results may be of particular pathophysiologic significance in the context of human atherosclerosis. Jonasson et al. (8), Gown et al. (9), and Emeson and Robertson (10) found that human atherosclerotic lesions contain $\mathrm{T}$ lymphocytes, cells capable of IFN- $\gamma$ production (15-17). Because many of the smooth muscle cells in lesions express surface HLA-DR antigens (11), and IFN- $\gamma$ is the only cytokine known to induce these antigens on human vascular cells (12-14), it is likely that leukocytes in the complicated human atherosclerotic plaque are activated and secrete this mediator locally.

Three major cell types found in the advanced human atheroma (endothelial cells, SMC, and mononuclear phagocytes) can each express IL 1 genes in vitro $(15,29,46)$. We recently demonstrated that IL 1 can be a potent stimulus for proliferation of human SMC (5). These findings revealed a novel link between mediators of the inflammatory and immune re- 
sponses and the control of proliferation of arterial SMC. The usual requirement for IL 1 in T cell activation together with evidence for activation of $\mathrm{T}$ cells within atheromata suggests the presence of this cytokine in the human atherosclerotic lesion.

If local IL 1 secretion contributes to the pathogenesis of human vascular diseases, our recent findings raise an interesting question. Because IL 1 begets further IL 1 gene expression in three cell types prominent in human atheromata (47-49), what prevents positive feedback from amplifying and propagating the inflammatory response or SMC proliferation in an uncontrolled fashion? IL 1 characteristically stimulates the cyclooxygenase pathway of target tissues. The major arachidonate product in human SMC treated with IL 1 is $\mathrm{PGE}_{2}$. We have found that $\mathrm{PGE}_{1}$ or $\mathrm{PGE}_{2}$ inhibits the responsiveness of human SMC to the mitogenic effect of IL 1 during short term incubations $(<4 \mathrm{~d})$. Concomitant treatment of SMC with a cyclooxygenase inhibitor blocks the IL 1-induced increase in $\mathrm{PGE}_{2}$ synthesis and uncovers IL 1's direct mitogenic effect on SMC (5). Thus IL 1's mitogenic effect on SMC is mitigated (in the short term at least) by simultaneous induction of a negative regulatory factor, $\mathrm{PGE}_{2}$. Because IFN- $\gamma$ is produced by $\mathrm{T}$ cells that may be activated in part by IL 1 , this pathway may provide another example of growth inhibition facilitated by IL 1 . The results of our long-term experiments indicate that this inhibitory effect is more sustained than that due to $\mathrm{PGE}_{2}$. The formation of the human atheroma is a prolonged process, its progression must depend in part on the dynamic balance between stimuli that promote and those which retard SMC growth. Our present data indicate that IFN- $\gamma$ may be one pathophysiologically significant inhibitor of SMC growth in the setting of the atherosclerotic plaque.

These various observations suggest a scenario in which a communication network mediated by inflammatory cytokines could play key roles in intercellular signalling in vascular pathophysiology. T cells, attracted to the developing atherosclerotic lesion by locally produced cytokines such as IL 1, become activated. The pathway of $T$ cell activation in the atheroma is incompletely understood at present. Although endogenous IL 1 might contribute to activation of T cells, this process usually also requires specific antigenic stimulus to induce production of activation-associated lymphokines such as IL 2 and IFN- $\gamma(15)$. Both the nature of the antigenic trigger to $T$ cell activation and the stimuli for local IL 1 gene expression in the vessel wall are currently unknown, and are fruitful subjects for further investigation. In any case, it is likely that some leukocytes in the plaque are activated to produce IFN- $\gamma$, since immune interferon appears necessary to induce HLA-DR antigen expression by SMC as found in the human lesion. Endothelial cells can produce type I IFN activity (50), but T lymphocytes are the probable source of immune IFN (a type II IFN) which activates HLA-DR expression. As shown here, the locally produced IFN- $\gamma$ could then antagonize IL 1 - or PDGF-induced SMC proliferation. Either cells of the vessel wall or infiltrating leukocytes could provide local sources of both of these well-characterized mitogens. The view of atherogenesis that emerges from this fusion of in vitro observations with results of studies on human tissues in situ highlights the dynamic aspects of the formation of these lesions, the potential importance of cells of the vessel wall themselves as sources of regulatory signals, and of interactions between leukocytes and SMC. The results presented here further illustrate how alter- ations in the balance of locally produced stimulatory and inhibitory cytokine messages may influence growth control and other aspects of vascular homeostasis.

\section{Acknowledgments}

The authors thank Maria W. Janicka, Cynthia B. Galin, and Nathan H. Margolis for excellent technical assistance. Dr. Robert N. Salomon provided assistance in the autoradiography of cell cultures. Joan L. Leonard provided dependable secretarial and administrative assistance.

These studies were supported by grant HL-34636 from the National Heart, Lung, and Blood Institute to P. Libby. S. J. C. Warner was the Howard B. Sprague Fellow of the American Heart Association, Massachusetts Affiliate, for 1987-1988. P. Libby is an Established Investigator of the American Heart Association.

\section{References}

1. Ross, R. 1986. The pathogenesis of atherosclerosis: an update. $N$. Engl. J. Med. 314:488-500.

2. Ross, R., J. A. Glomset, B. Kariya, and L. Harker. 1974. A platelet-dependent serum factor that stimulates the proliferation of arterial smooth muscle cells in vitro. Proc. Natl. Acad. Sci. USA. 71:1207-1210.

3. Antoniades, H. N., D. Stathakos, and C. D. Scher. 1975. Isolation of a cationic polypeptide from human serum that stimulates proliferation of 3T3 cells. Proc. Natl. Acad. Sci. USA. 72:2635-2639.

4. Heldin, C. H., B. Westermark, and Å. Wasteson. 1979. Plateletderived growth factor: purification and partial characterization. Proc. Natl. Acad. Sci. USA. 76:3722-3726.

5. Libby, P., S. J. C. Warner, and G. B. Friedman. 1988. Interleukin 1: a mitogen for human vascular smooth muscle cells that induces the release of growth-inhibitory prostanoids. J. Clin. Invest. 81:487498.

6. Madtes, D. K., E. W. Raines, K. S. Sakariassen, R. K. Assoian, M. B. Sporn, G. I. Bell, and R. Ross. 1988. Induction of transforming growth factor-alpha in activated human alveolar macrophages. Cell. 53:285-293.

7. Castellot, J. J., Jr., M. L. Addonizio, R. Rosenberg, and M. J. Karnovsky. 1981. Cultured endothelial cells produce a heparin-like inhibitor of smooth muscle cell growth. J. Cell. Biol. 90:372-379.

8. Jonasson, L., J. Holm, O. Skalli, G. Bonders, and G. K. Hansson. 1986. Regional accumulations of $\mathrm{T}$ cells, macrophages, and smooth muscle cells in the human atherosclerotic plaque. Arteriosclerosis. 6:131-138.

9. Gown, A. M., T. Tsukada, and R. Ross. 1986. Human atherosclerosis II. Immunocytochemical analysis of the cellular composition of human atherosclerotic lesions. Am. J. Pathol. 125:191-207.

10. Emeson, E. E., and A. L. Robertson, Jr. 1988. T lymphocytes in aortic and coronary intimas. Their potential role in atherogenesis. $\mathrm{Am}$. J. Pathol. 130:369-376.

11. Hansson, G. K., L. Jonasson, J. Holm, and L. Claesson-Welsh. 1986. Class II MHC antigen expression in the atherosclerotic plaque: smooth muscle cells express HLA-DR, HLA-DQ and the invariant gamma chain. Clin. Exp. Immunol. 64:261-268.

12. Warner, S. J. C., G. B. Friedman, and P. Libby. 1989. The regulation of major histocompatibility gene expression in cultured human vascular smooth muscle cells. Arteriosclerosis. In press.

13. Hansson, G. K., L. Jonasson, J. Holm, M. K. Clowes, and A. Clowes. 1988. Gamma interferon regulates vascular smooth muscle proliferation and la expression in vivo and in vitro. Circ. Res. 63:712719.

14. Pober, J. S., T. Collins, M. A. Gimbrone, Jr., P. Libby, and C. S Reiss. 1986. Inducible expression of class II major histocompatibility complex antigens and the immunogenicity of vascular endothelium. Transplantation. 41:41-46.

15. Dinarello, C. A., and J. W. Mier. 1987. Lymphokines. N. Engl. J. Med. 317:940-945. 
16. Nathan, C. F., H. W. Murray, M. E. Weibe, and B. Y. Rubin. 1983. Identification of interferon- $\gamma$ as the lymphokine that activates human macrophage oxidation and antimicrobial activity. J. Exp. Med. 158:670-689.

17. Robinson, B. W., T. L. McLemore, and R. G. Crystal. 1985. Gamma interferon is spontaneously released by alveolar macrophages and lung $\mathrm{T}$ lymphocytes in patients with pulmonary sarcoidosis. $J$. Clin. Invest. 75:1488-1495.

18. Pestka, S., J. A. Langer, K. C. Zoon, and C. E. Samuel. 1987. Interferons and their actions. Annu. Rev. Biochem. 56:727-777.

19. Heyns, A. du P., A. Eldor, I. Vlodavsky, N. Kaiser, R. Friedman, and A. Panet. 1985. The antiproliferative effect of interferon and the mitogenic activity of growth factors are independent cell cycle events. Exp. Cell Res. 161:297-306.

20. Taylor-Papadimitriou, J., T. Higgins, M. Shearer, and E. Rozengurt. 1986. Inhibition of cell growth by interferon: an analysis using quiescent fibroblasts stimulated by PDGF and other growth factors. In Interferons as Cell Growth Inhibitors and Antitumor Factors. Robert M. Friedman, Thomas Merigan, and T. Sreevalsan, editors. Alan R. Liss, Inc., New York. 481-495.

21. Friedman, R. M. 1986. Growth factors, oncogenes, and interferons. J. Exp. Pathol. 2:223-228.

22. Chebath, J., P. Benech, Y. Mory, L. Mallucci, R. Michalevicz, and M. Revel. 1986. IFN and (2'-5') oligo A synthetase in cell growth and in differentiation of hematopoietic cells. In Interferons as Cell Growth Inhibitors and Antitumor Factors. R. M. Friedman, T. Merigan, and T. Sreevalsan, editors. Alan R. Liss, Inc., New York. 351-363.

23. Revel, M., A. Kimchi, M. Friedman, D. Wolf, G. Merlin, A. Panet, S. Rapoport, and Y. Lapidot. 1981. Cell-regulatory functions of interferon induced enzymes: antimitogenic effect of $\left(2^{\prime}-5^{\prime}\right)$ oligo-A, growth-related variations in $\left(2^{\prime}-5^{\prime}\right)$ oligo-A synthetase, and isolation of its mRNA. Tex. Rep. Biol. Med. 41:452-458.

24. Lin, S. L., T. Kikuchi, W. J. Pledger, and I. Tamm. 1986. Interferon inhibits the establishment of competence in $\mathrm{G}_{0} / \mathrm{S}$-phase transition. Science (Wash. DC). 233:356-359.

25. Kimchi, A., H. Shure, Y. Lapidot, S. Rapoport, A. Panet, and M. Revel. 1981. Antimitogenic effects of interferon and 2'-5'-oligoadenylate in synchronized 3T3 fibroblasts. FEBS (Fed. Eur. Biochem. Soc.) Lett. 134:212-216.

26. Friesel, R., A. Komoriya, and T. Maciag. 1987. Inhibition of endothelial cell proliferation by gamma-interferon. J. Cell Biol. 104:689-696.

27. Pfeffer, L. M., and I. Tamm. 1984. Interferon inhibition of thymidine incorporation into DNA through effects on thymidine transport and uptake. J. Cell. Physiol. 121:431-436.

28. Hunninghake, G. W., C. Hemken, M. Brady, and M. Monick. 1986. Immune interferon is a growth factor for human lung fibroblasts. Am. Rev. Respir. Dis. 134:1025-1028.

29. Libby, P., J. M. Ordovas, L. K. Birinyi, K. R. Auger, and C. A. Dinarello. 1986. Inducible interleukin-1 expression in human vascular smooth muscle cells. J. Clin. Invest. 78:1432-1438.

30. Kluger, M. J., R. Singer, and S. M. Eiger. 1985. Polymyxin B use does not ensure endotoxin-free solution. J. Immunol. Methods. 83:201-207.

31. Ross, R., and B. Kariya. 1980. Morphogenesis of vascular smooth muscle in atherosclerosis and cell structure. In Handbook of Physiology: The Cardiovascular System. Vol. 2. D. F. Bohr, A. P. Somlyo, and H. Y. Sparks, editors. American Physiological Society, Bethesda, MD. 69-91.

32. Tsukada, T., D. Tippens, D. Gordon, R. Ross, and A. M. Gown. 1987. HHF35, A muscle-actin-specific monoclonal antibody. Am. J. Pathol. 127:51-60.

33. Libby, P., and K. V. O'Brien. 1983. Culture of quiescent vascu- lar smooth muscle cells in a defined serum-free medium. J. Cell. Physiol. 115:217-223.

34. West, D. C., S. Sattar, and S. Kumar. 1985. A simplified in situ solubilization procedure for the determination of DNA and cell number in tissue cultured mammalian cells. Anal. Biochem. 147:289-295.

35. Revel, M., D. Wallach, G. Merlin, A. Schattner, A. Schmidt, D. Wolf, L. Shulman, and A. Kimchi. 1981. Interferon-induced enzymes: microassays and their applications; purification and assay of $\left(2^{\prime}-5^{\prime}\right)$ oligoadenylate synthetase and assay of 2'-phosphodiesterase. Methods Enzymol. 79:149-161.

36. Chomczynski, P., and N. Sacchi. 1987. Single-step method of RNA isolation by acid guanidinium thiocyanate-phenol-chloroform extraction. Anal. Biochem. 162:156-159.

37. Feinberg, A. P., and B. Vogelstein. 1983. A technique for radiolabeling DNA restriction endonuclease fragments to high specific activity. Anal. Biochem. 132:6-13.

38. Benech, P., Y. Mory, M. Revel, and J. Chebath. 1985. Structure of two forms of the interferon-induced $\left(2^{\prime}-5^{\prime}\right)$ oligo A synthetase of human cells based on CDNAs and gene sequences. EMBO (Eur. Mol. Biol. Organ.) J. 4:2249-2256.

39. Bond, J. F., and S. R. Farmer. 1983. Regulation of tubulin and actin mRNA production in rat brain: expression of a new beta-tubulin mRNA with development. Mol. Cell. Biol. 3:1333-1342.

40. Ross, R., C. Nist, B. Kariya, M. J. Rivest, E. Raines, and J. Callis. 1978. Physiological quiescence in plasma-derived serum: influence of platelet-derived growth factor on cell growth in culture. J. Cell. Physiol. 97:497-508.

41. Nilsson, J., M. Sjolund, L. Palmberg, J. Thyberg, and C. H. Heldin. 1985. Arterial smooth muscle cells in primary culture produce a platelet-derived growth factor-like protein. Proc. Natl. Acad. Sci. USA. 82:4418-4422.

42. Walker L. N., D. F. Bowen-Pope, R. Ross, and M. A. Reidy. 1986. Production of platelet-derived growth factor-like molecules by cultured arterial smooth muscle cells accompanies proliferation after arterial injury. Proc. Natl. Acad. Sci. USA. 83:7311-7315.

43. Libby, P., S. J. C. Warner, R. N. Salomon, and L. K. Birinyi. 1988. Production of platelet-derived growth factor-like mitogen by smooth-muscle cells from human atheroma. N. Engl. J. Med. 318:1493-1498.

44. Dean, M., R. A. Levine, W. Ran, M. S. Kindy, G. E. Sonenshein, and J. Campisi. 1986. Regulation of c-myc transcription and mRNA abundance by serum growth factors and cell contact. J. Biol. Chem. 261:9161-9166.

45. Kuo, P. T., A. C. Wilson, R. C. Goldstein, and R. G. Schaub. 1984. Supression of experimental atherosclerosis in rabbits by interferon-inducing agents. J. Am. Coll. Cardiol. 3:129-134.

46. Libby, P., J. M. Ordovas, K. R. Auger, A. H. Robbins, L. K. Birinyi, and C. A. Dinarello. 1986. Endotoxin and tumor necrosis factor induce interleukin-1 beta gene expression in adult human vascular endothelial cells. Am. J. Pathol. 124:179-185.

47. Warner, S. J. C., K. R. Auger, and P. Libby. 1987. Human interleukin 1 induces interleukin 1 gene expression in human vascular smooth muscle cells. J. Exp. Med. 165:1316-1331.

48. Dinarello, C. A., T. Ikejima, S. J. C. Warner, S. F. Orencole, G. Lonneman, J. G. Cannon, and P. Libby. 1987. Interleukin 1 induces interleukin 1. I. Induction of circulating interleukin 1 in rabbits in vivo and in human mononuclear cells in vitro. J. Immunol. 139:19021910.

49. Warner, S. J. C., K. R. Auger, and P. Libby. 1987. Interleukin 1 induces interleukin 1 II. Recombinant human interleukin 1 induces interleukin 1 production by adult human vascular endothelial cells. $J$. Immunol. 139:1911-1917.

50. Einhorn, S., A. Eldor, I. Vlodavsky, Z. Fuks, and A. Panet. 1985. Production and characterization of interferon from endothelial cells. J. Cell. Physiol. 122:200-204. 